\title{
STUDI FASIES FORMASI ENDAPAN DANAU UNTUK MENENTUKAN LINGKUNGAN PENGENDAPAN DANAU LIMBOTO
}

\author{
Abd Kadir Mubarak A Amin ${ }^{a}$, Yayu Indriati Arifin ${ }^{a}$, Noviar Akase ${ }^{a}$ \\ a Jurusan Ilmu dan Teknologi Kebumian, Program Studi Teknik Geologi, F.MIPA, Universitas Negeri Gorontalo, Jl. Jenderal \\ Sudirman No. 6, Dulalowo Timur, Kota Tengah, Gorontalo 96128, Indonesia.
}

\section{INFO ARTIKEL}

\section{Status artikel:}

Diterima: 18 Februari 2019

Disetujui: 9 Juli 2019

Tersedia online: 11 Juli 2019

\section{Kata kunci:}

Deposits Formation; Formation Facies Lake; Geological Mapping;

Sedimentation

\section{Penulis korespondensi:}

Abd Kadir Mubarak A Amin

Jurusan Ilmu dan Teknologi

Kebumian, Program Studi Teknik

Geologi, F.MIPA, Universitas Negeri

Gorontalo, Gorontalo, Indonesia.

Email: mubarrack95@gmail.com

\begin{abstract}
The research area located in the lowland zone and the corrugated hilly zone which is dominated by sedimentary rocks. Therefore, this study aims to determine the geological features of the research area and the study of depositional environmental facies of the Lake Deposits Formation as an analysis of the depositional environment of Limboto Lake. The research method used is the surface geological mapping, measuring section of stratigraphic and laboratory analysis. Field data consists stratigraphycal features of research area. Laboratory analysis consists of petrography and stratigraphy-sedimentology analysis. It can be concluded facies and stratigraphy of research from older to youngest, consists of clastic limestones unit formed in Late Miocene-late Early Pliocene age, reef limestones formed in Late Miocene-early Late Pliocene age, sandstones unit formed in Late Pliocene-Pleistocene age, clay unit and sandy clay unit are deposited in Holocene. Overall the study site consisted of marine, transitional and terrestrial deposition environment with Lake Deposits Formation facies is lake margin clastic deposits and meandering-stream environment deposits.
\end{abstract}

Copyright (C) 2019 JGeosREV-UNG This open access article is distributed under Creative Commons Attribution (CC-BY) 4.0 International license

\section{Pendahuluan}

Danau Limboto yang terletak di Provinsi Gorontalo memiliki fungsi yang sangat penting bagi ekosistem yang ada disekitar danau, baik flora maupun fauna serta masyarakat disekitaran danau yang saat ini keberadaannya terancam hilang dikarenakan pendangkalan danau yang signifikan serta berbagai potensi masalah lingkungan yang akan dihasilkan. Secara geologi, Danau Limboto merupakan sebagian tempat dimana tersingkapnya berbagai jenis batuan salah satunya batuan sedimen serta berbagai deformasi tektonik (Satyana et al., 2011). Menurut Putra et al., (2012) berdasarkan genesis formasi Danau Limboto merupakan cekungan rendah atau laguna yang juga termasuk dalam tipe danau dangkal atau tipe paparan banjir (dataran banjir).

Cekungan atau Depresi Limboto terbentuk dimulai dari adanya Ekstensi Neogen yang menyebabkan tumbukan serta penyebaran zona sesar yang besar dan pembalikan subduksi (subduction roll back) di Busur Banda sekitar awal hingga pertenghaan Miosen. Pada akhir Miosen kembali terjadi Ekstensi besar yang menyebabkan pengangkatan dan penurunan cepat di Cekungan Gorontalo dan Sekitarnya (Rudyawan et al., 2014). Pengaruh aktivitas tektonik khususnya di lengan utara Sulawesi mempengaruhi lingkungan pengendapan dikaitkan pada variasi litologi yang tersingkap (Van Leeuwen \& Muhardjo, 2005). Hal tersebut menjadikan daerah Danau Limboto menarik untuk dilakukan penelitian terhadap studi lingkungan pengendapan danau.

Tujuan dari penelitian ini untuk mengetahui tatanan geologi daerah Dungaliyo hingga Danau Limboto dan sekitarnya secara rinci yang meliputi geomorfologi, litologi, struktur geologi, stratigrafi dan secara khusus untuk mendeskripsikan fasies Formasi Endapan Danau dan menafsirkan lingkungan pengendapannya serta hubungannya dengan aktivitas tektonik terhadap pembentukan cekungan danau. 


\section{Metodologi}

\subsection{Lokasi Penelitian}

Daerah penelitian secara berada pada 0 $34^{\prime} 30^{\prime \prime}-0^{\circ} 37^{\prime} 30^{\prime \prime}$ LU dan $122^{\circ} 52^{\prime} 5^{\prime \prime}$ - $122^{\circ} 58^{\prime} 20^{\prime \prime}$ BT tepatnya terletak pada sebagian besar di Kecamatan Dungaliyo, Tabongo, Kecamatan Limboto, Kecamatan Limboto Barat, sebagian kecil Kecamatan Tibawa dan Kecamatan Batudaa (Gambar 1). Kabupaten Gorontalo, Provinsi Gorontalo. Luas daerah $\pm 66 \mathrm{Km}^{2}$, dengan keseluruhan daerah dilakukan pemetaan geologi dan studi khusus dilakukan di sepanjang aliran sekitar hulu DAS Alopohu hingga Danau Limboto.

\subsection{Tahapan Penelitian}

Metode penelitian yang digunakan adalah metode pemetaan geologi dan pengukuran penampang stratigrafi (measuring section) permukaan. Metode yang dilakukan telah melalui beberapa tahap, yaitu tahapan persiapan, studi pendahuluan, pengambilan data, analisis dan pengolahan data serta penyajian data.

Pada tahap analisis dan pengolahan data dengan studi sedimentologi dan stratigrafi detail, terdiri atas tahapan preparasi sampel, tahapan analisis data serta tahapan pembuatan hasil analisa profil dilakukan di laboratorium dan studio. Tahap ini didukung dengan studi pustaka. Preparasi Sampel terdiri atas preparasi sampel untuk keperluan analisa petrografi, keperluan analisis mikrofosil dan sampel.

Tahapan Analisis terbagi atas analisis geomorfologi berdasarkan data dekomentasi gemorfologi lapangan dikolaborasikan bersama data citra Worldview dan foto udara. Analisis petrografi dengan batuan diklasifikasikan yang dikembangkan oleh Pettijohn (1975), Embry \& Klovan (1971). Analisis struktur geologi berdasarkan pendekatan geometri yang meliputi analisis deskriptif, Analisis stratigrafi dan sedimentologi dilakukan untuk rekonstruksi stratigrafi dan diklasifikasikan menurut fasies pengendapan sedimen seperti yang dikembangkan Tipsword et al., (1966), Analisis ini didasarkan pada hasil pengukuran penampang stratigrafi terukur (measuring section). Analisis umur satuan berdasarkan zonasi keterdapatan mikrofosil yang dikembangkan oleh Blow (1969) serta data carbon dating.

\section{Hasil dan Pembahasan}

\subsection{Formasi dan Lingkungan Pengendapan}

Berdasarkan hasil pengamatan lapangan dan pengambilan data stratigrafi, daerah penelitian terdiri atas beberapa formasi, berupa Formasi Non-Endapan Danau dan Formasi Endapan Danau. Formasiformasi tersebut dibedakan berdasarkan ciri litologi dan mekanisme lingkungan pengendapannya.

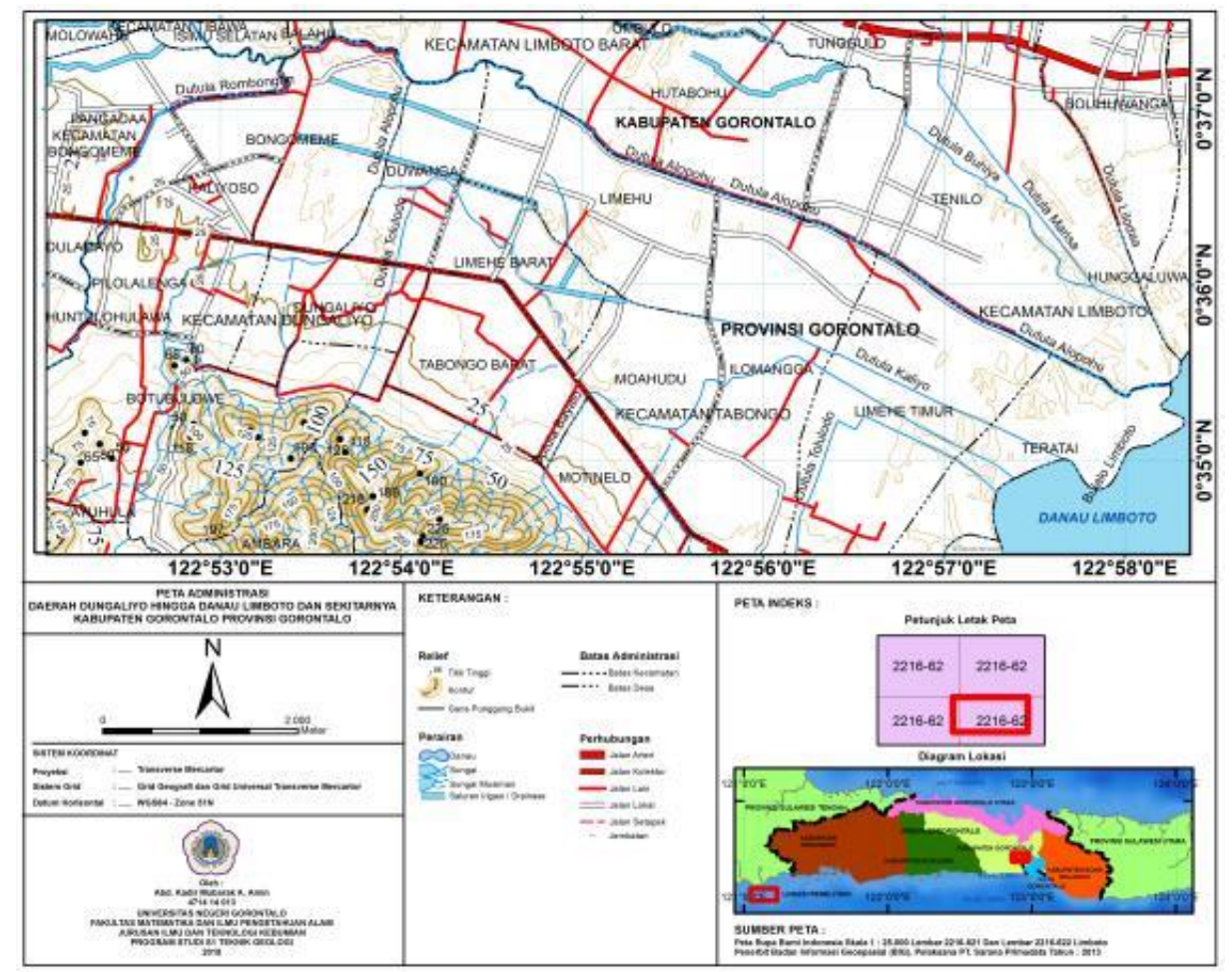

Gambar 1. Peta Lokasi Penelitian (Digambar kembali dari BIG, 2013) 


\subsection{Formasi Non-endapan Danau}

\subsubsection{Satuan batugamping klastik}

Litologi penyusun satuan ini terutama grainstone dan tufa. Grainstone menunjukkan ciri-ciri dengan warna segar putih kecokelatan, tekstur klastik, agak kompak, struktur berlapis dengan kenampakkan sisa hasil pertumbuhan terumbu karang dan terdapat fosil dari filum moluska pada klas gastropoda, karbonatan, sehingga dinamakan batugamping klastik, namun setempat dijumpai tufa setempat telah mengalami alterasi (Gambar 2f, g, h).

Tuf berwarna segar putih, lapuk cokelat kekuningan, secara umum berukuran $<2 \mathrm{~mm}$ yang tersusun atas butiran kristal terutama plagioklas, kuarsa, mineral opak dan litik yang diwakili oleh fragmen tufa yang terubah menjadi mineral lempung. Semen setempat karbonatan, matriks gelas, setempat membentuk cuspate akibat gelas terelaskan secara kuat (densely welded) berukuran abu $(<2 \mathrm{~mm})$, pemilahan buruk, kemas terbuka, matriks supported, kekompakkan sedang, porositas tinggi. Teramati di lapangan berlapis baik dengan ketebalan $\pm 40 \mathrm{~cm}$ tetapi tidak ditemukan kemenerusan lapisan di beberapa lokasi pengamatan sehingga diinterpretasikan batuan ini hanya sebagai sisipan.
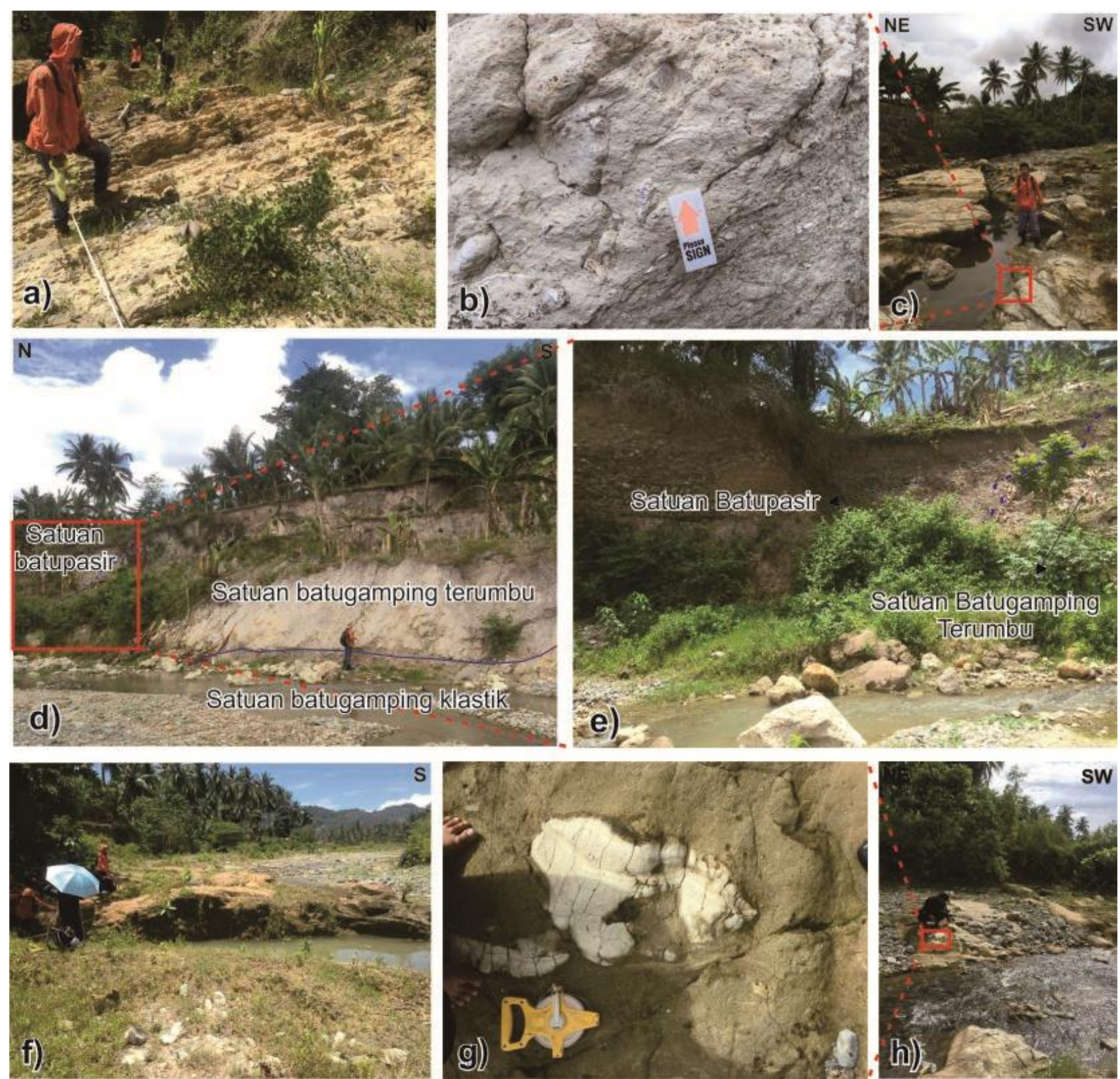

Gambar 2. Pengamatan lapangan pada satuan batugamping klastik, a), b) dan c) perlapisan grainstone terlihat banyak pecahan terumbu dan moluska (stasiun BR007), d) dan e) kontak antara satuan batugamping klastik, satuan batugamping terumbu dan satuan batupasir (biru putus-putus:tidak selaras, biru tegas:selaras) (stasiun BR041), f), g) dan h) kenampakan tuff dilapangan pada perlapisan satuan batugamping klastik (stasiun BR007). 


\subsubsection{Satuan batugamping terumbu}

Litologi penyusun satuan ini terutama rudstone, napal, mudstone dan tufa. Terumbu berwarna putih keabu-abuan, bio-klastik, umumnya berupa terumbu dan moluska besar, masif, komposisi karbonat sehingga dinamakan batugamping terumbu yang merupakan batugamping bio-klastik (Gambar 3). Rudstone menunjukkan ciri-ciri dengan warna segar putih kecokelatan, warna lapuk kehitaman, tekstur tumbuh, kompak, setempat berlapis dengan kenampakkan sisa hasil pertumbuhan terumbu karang dan terdapat fosil dari filum moluska pada klas gastropoda dan bivalvia, karbonatan, setempat dijumpai berulapis dengan sisipan mudstone dan tufa karbonatan serta napal dengan banyak kandungan mikrofosil. Mudstone berwarna putih kecoklatan, tekstur klastika dengan komponen dominan lumpur karbonat, setempat mengandung pecahan koral, cangkang moluska yang tertanam dalam lumpur karbonat, kurang kumpak setempat dijumpai fragmen tufa gampingan.

Tufa berwarna segar putih, lapuk cokelat kekuningan, secara umum berukuran $<2 \mathrm{~mm}$ yang tersusun atas fragmen kristal plagioklas, kuarsa dan gelas, yang sebagian tersemenkan oleh kalsit. Butiran kristal dominan kalsit yang dicirikan dengan kenampakan mosaic diantara shards gelas memperlihatkan bias
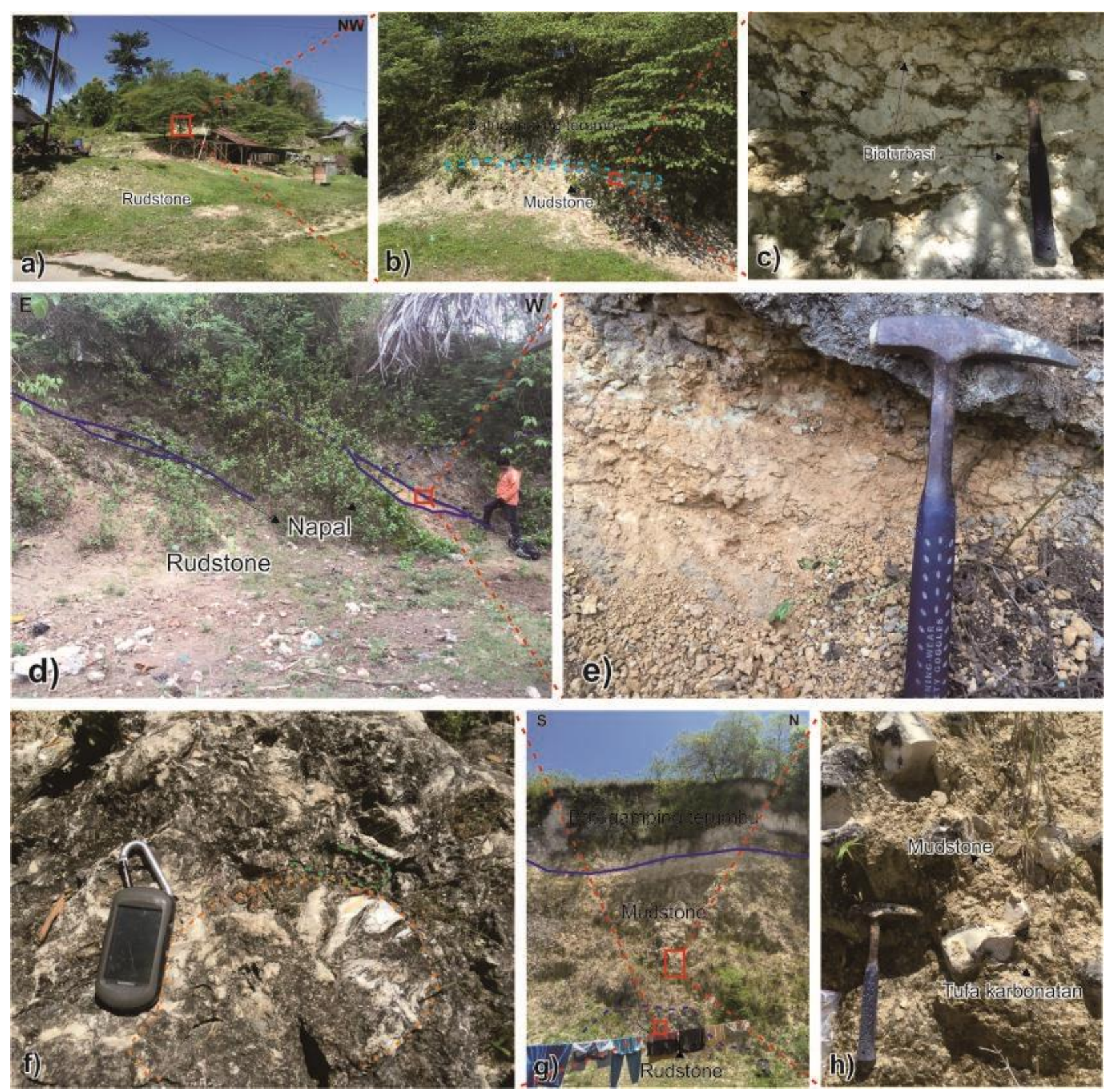

Gambar 3. Pengamatan lapangan pada satuan batugamping bio-klastik, a), b) dan c) perlapisan batugamping mudstone dan rudstone (stasiun BR004), d) dan e) kontak antara satuan batugamping terumbu dengan napal (stasiun BR033), f), g) dan h) perlapisan batugamping mudstone, rudstone dan tufa (stasiun BR005). 

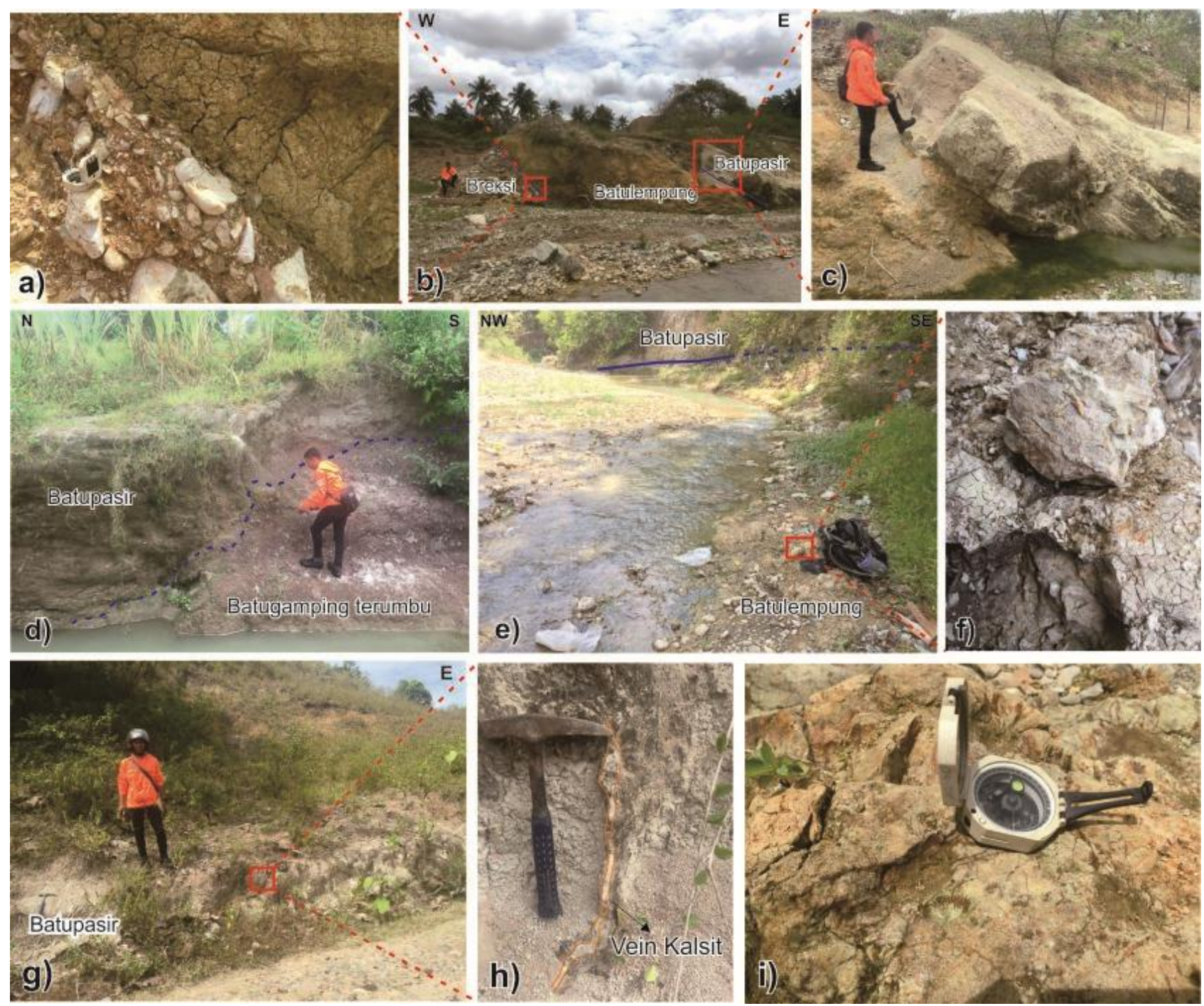

Gambar 4. a), b) dan c) Kontak keselarasan antara breksi, batulempung dan batupasir (stasiun BR042), d) kontak ketidakselarasan antara satuan batugamping terumbu dengan satuan batupasir (stasiun BR039), e) dan f), kontak selaras antara batulempung dan batupasir serta kenampakan pecahan-pecahan terumbu dan moluska pada batulempung (stasiun BR064), g) dan h), kenampakan batupasir dengan vein kalsit yang terbentuk (stasiun BR047), i) kenampakan sisa jejak tempat cangkang bivalvia pada litologi batulempung (stasiun BR041).

rangkap tinggi, kuarsa berukuran $0.05 \mathrm{~mm}-0.1 \mathrm{~mm}$, hadir setempat diantara gelas dan kalsit. Teramati di lapangan sebagai pecahan fragmen besar pengisi mudstone dengan ketebalan $\pm 12 \mathrm{~cm}$ tetapi tidak ditemukan kemenerusan lapisan di beberapa lokasi pengamatan sehingga diinterpretasikan batuan ini hanya sebagai sisipan. Satuan batugamping terumbu merupakan kelompok litologi yang berkembang di wilayah perbukitan selatan daerah penelitian. Satuan ini menempati luas kurang lebih $9 \mathrm{Km}^{2}$ atau 13.3 $\%$ daerah penelitian

\subsubsection{Satuan batupasir}

Litologi penyusun satuan ini berupa batupasir, batulempung dan breksi. Batupasir berwarna abu-abu kocokelatan, fragmen berupa litik, kuarsa dan plagioklas, berukuran pasir sedang hingga pasir sangat kasar, angular-subangular, terpilah sedang, matrik pasir sangat halus, semen bersifat silika setempat gampingan, setempat terdapat vein-vein kalsit, kekompakan sedang, porositas baik, kemas terbuka (clast supported) (Gambar 4).

Breksi berwarna abu-abu kecokelatan, fragmen litik beripa andesit, diorit, grandiorit dan fosil kayu, matrik pasir sedang hingga kasar, semen bersifat silika, kekompakan sedang, porositas baik serta kemas terbuka (clast supported). Batulempung warna kecokelatan hingga hitam, setempat banyak mengandung pecahan fosil moluska berupa gastropoda dan bivalvia serta pecahan terumbu, padat setempat pecah-pecah (Gambar 4a dan 4b). 


\subsection{Formasi Endapan Danau}

\subsubsection{Satuan lempung}

Litologi penysusun satuan ini berupa perselingan lempung dan pasir yang termampatkan lemah didasarkan pada data lapangan dan data bor oleh BWS II Sulawesi (2018b). Pasir berwarna abu-abu, lepas, berbutir halus-sedang, dapat diuraikan dengan tangan, memperlihatkan tekstur menghalus keatas, pemilahan baik setempat banyak mengandung pecahan terumbu dan fosil moluska.

Lempung abu-abu terang, lembut, dapat diuraikan dengan tangan, plastisitas tinggi, kaya akan endapan organik berupa akar, pecahan terumbu serta fossil. Batupasir berwarna abu-abu kocokelatan, fragmen berupa litik, kuarsa dan plagioklas, berukuran pasir sedang hingga pasir sangat kasar, angularsubangular, terpilah sedang, matrik pasir sangat halus, semen bersifat silika setempat gampingan, setempat terdapat vein-vein kalsit, kekompakan sedang, porositas baik, kemas terbuka (clast supported). Setempat banyak mengandung pecahan fosil moluska berupa gastropoda dan bivalvia serta pecahan terumbu, padat setempat pecah-pecah (Gambar 5).

\subsubsection{Satuan lempung pasiran}

Litologi penyusun satuan ini merupakan endapan fluvial. Terdiri atas umumnya berupa material lepas yang berukuran lempung, pasir serta kerikil yang berukuran kerikil hingga kerakal berbentuk angular
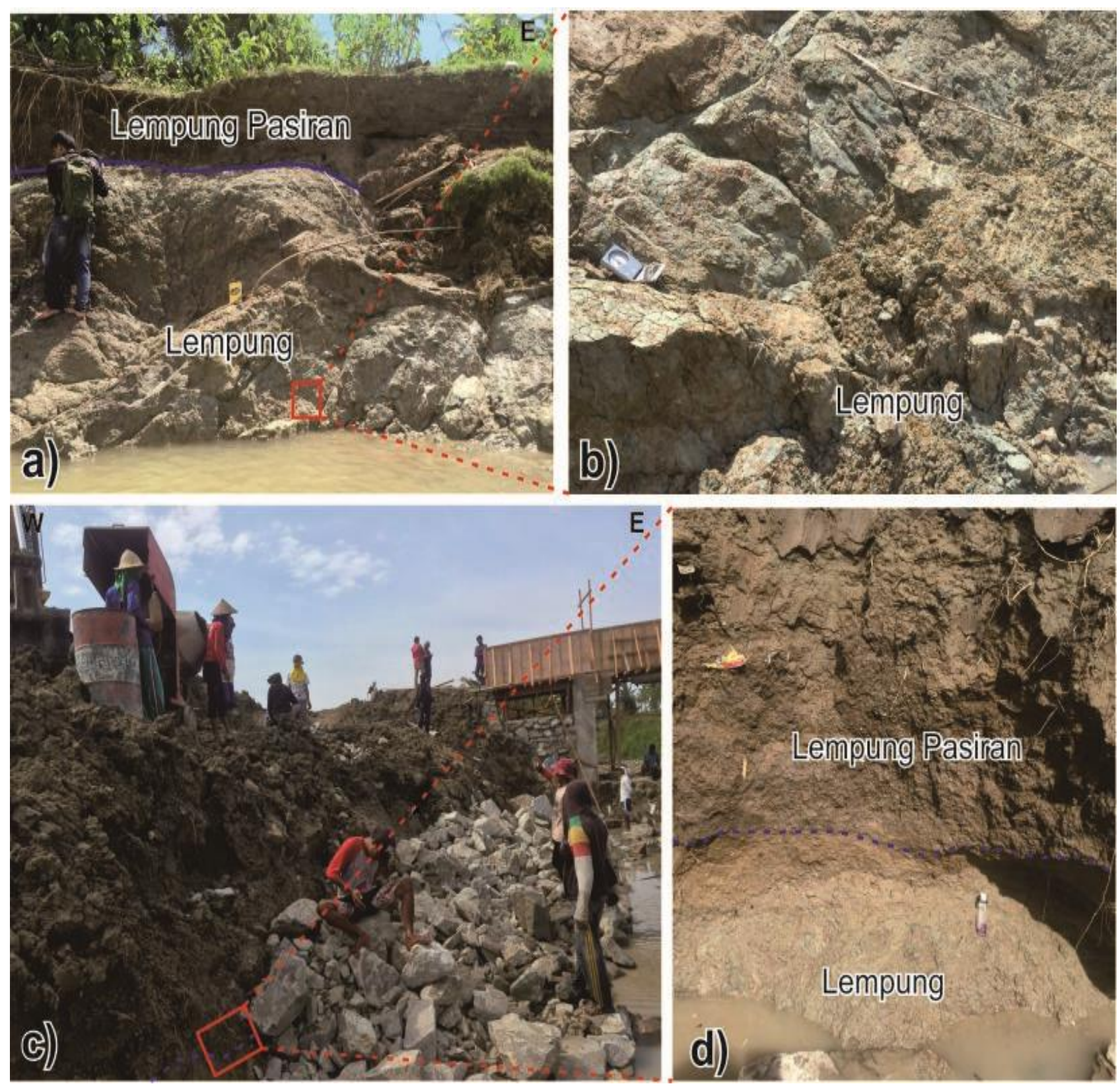

Gambar 5. Kontak antara satuan lempung dan satuan lempung Pasiran a) dan b) (stasiun BR002) c) dan d) (stasiun BR071). 


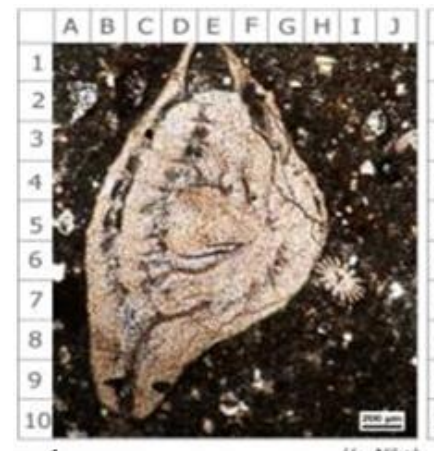

1
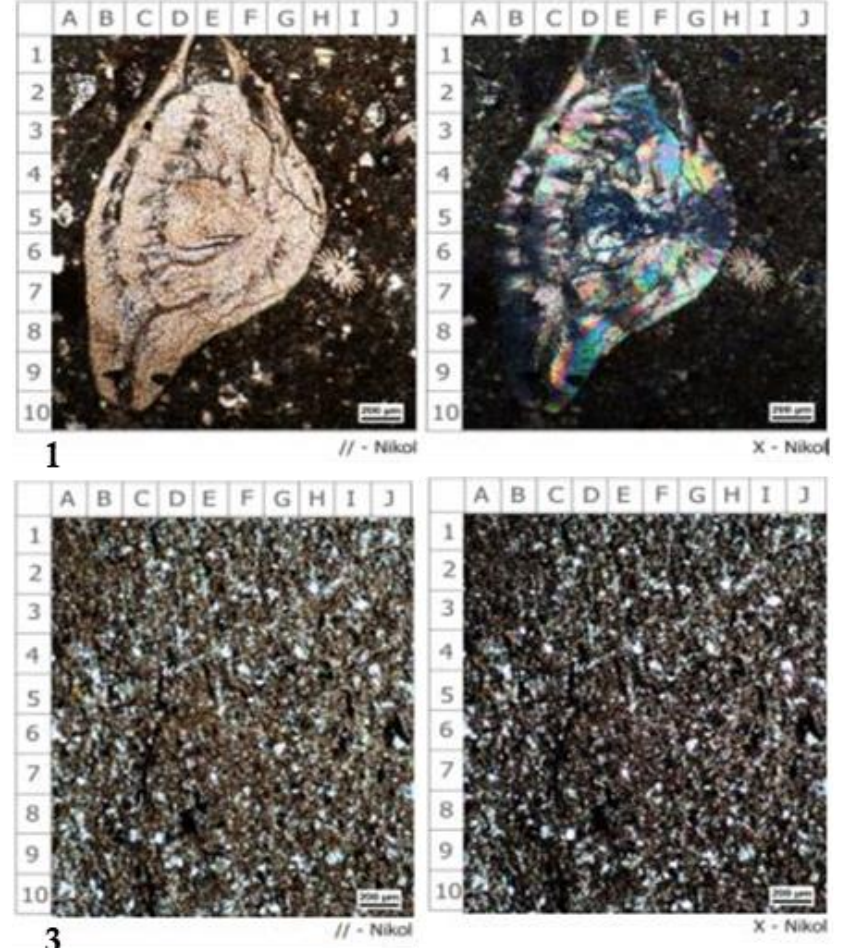

Gambar 6. Kenampakan cangkang dan mikrit pada sayatan tipis grainstone (BR007) (1), Kenampakan tufa pada sayatan tipis (BR007) (2), Kenampakan batulempung pada sayatan tipis (BR007) (3) dam Kenampakan pasir pada sayatan tipis (Stasiun BR003) (4)

hingga membulat tersusun atas pecahan batuan, mineral mafik, kuarsa, plagioklas, ortoklas serta sebagian pasir bersifat besian (Gambar 6).

\subsection{Fasies Formasi Endapan Danau}

Berdasarkan beberapa peneliti terdahulu bahwa Formasi Endapan Danau terdiri atas batupasir, batulempung dan kerikil. Formasi ini merupakan hasil dari endapan aliran gravitasi di lingkungan danau darat. Sebagian anggota satuan formasi Endapan Danau merupakan endapan teras (Bawono et al., 1999). Berdasarkan data lapangan meliputi litologi, geometri lapisan, struktur sedimen, iknofasies, dan data bor serta kesebandingan geologi regional lembar Limboto skala 1:100.000 (Bawono et al., 1999) secara keseluruhan lokasi penelitian terdiri dari zona pengendapan laut, transisi serta teresterial (Gambar 7).

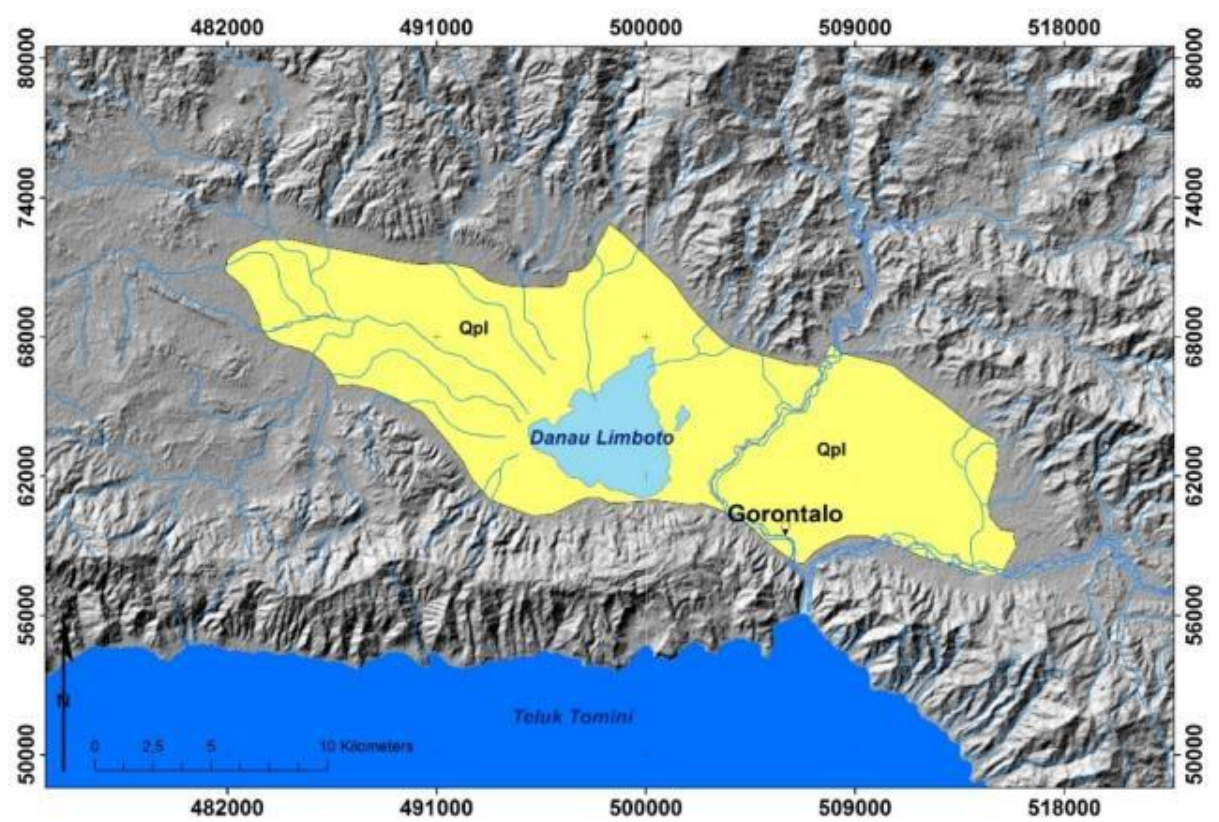

Gambar 7. Penyebaran Formasi Endapan Danau di Cekungan Limboto, dimodifikasi dari Bawono et al., (1999); Apandi \& Bachri (1997) 


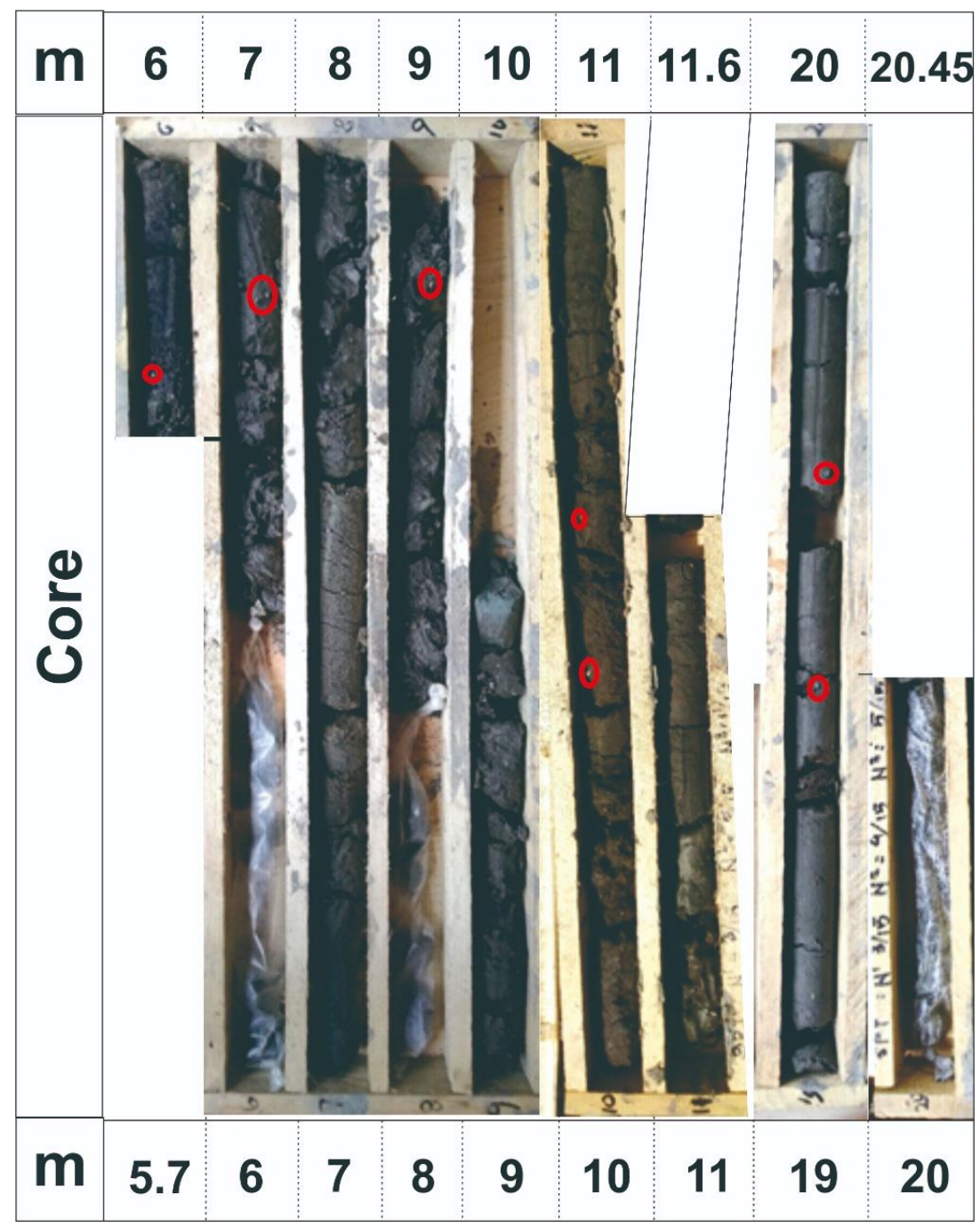

Gambar 8. Kenampakan fosil moluska pada core box 1 ditandai oleh warna merah (BWS Sulawesi II, 2018b)

Aktivitas tektonisme pada daerah penelitian dimulai pada Miosen hingga Plistosen, dimana pala kala ini adalah proses pembentukan cekungan Limboto hingga terpisah dengan muka air laut. Juga didasarkan pada keadaan paleogeografi Sulawesi yang dimodelkan oleh Nugraha \& Hall (2018) dimana muka air laut pada akhir plistosen mencapai cekungan-cekungan darat yang ada pada Lembah Paguyaman dan Lembah Limboto.

Berdasarkan data lapangan serta Peta Geologi Regional Lembar Limboto skala 1:100.000 (Bawono et al., 1999) dan data lapangan serta pengeboran geologi oleh BWS Sulawesi II (2018b) Formasi Endapan Danau tersebar merata hampir di seluruh cekungan Limboto dan dapat dapat disimpulkan Formasi Endapan Danau terendapakan pada fasies dan lingkungan teresterial dimana terdiri atas lingkungan lake margin clastic deposit dan meandering-stream deposit.

\subsubsection{Fasies lake margin clastic deposits}

Fasies Lake Margin Clastic Deposits berdasarkan hasil pengukuran penampang stratigrafi terukur terdiri atas subfasies rawa danau dan menurut BWS Sulawesi II (2018b) yaitu hasil pengeboran juga terdiri atas subfasies berupa deltaik danau dan pantai danau (Gambar 8). Pada daerah penelitian, fasies ini dicirikan oleh dominasi endapan-endapan rawa danau (lacustrine swamp) yang cukup intensif. Litologi yang ditemukan berupa lempung dan pasir berukuran butir dari lempung hingga pasir sangat halus serta ditemukan banyak fosil moluska yang tersebar umumnya pada litologi lempung juga banyak ditemukan struktur bioturbasi dari jejak jejak akar ataupun makhluk hidup. Fasies ini merupakan fasies tertua dari Formasi Endapan Danau dan berlangsung hingga saat ini.

\subsubsection{Fasies meandering-stream deposits}

Fasies Meandering terdiri atas subfasies berupa fasies dataran banjir, natural levee, dan channel sungai. Fasies ini dicirikan oleh dominasi endapan-endapan channel yang cukup intensif. Litologi yang 

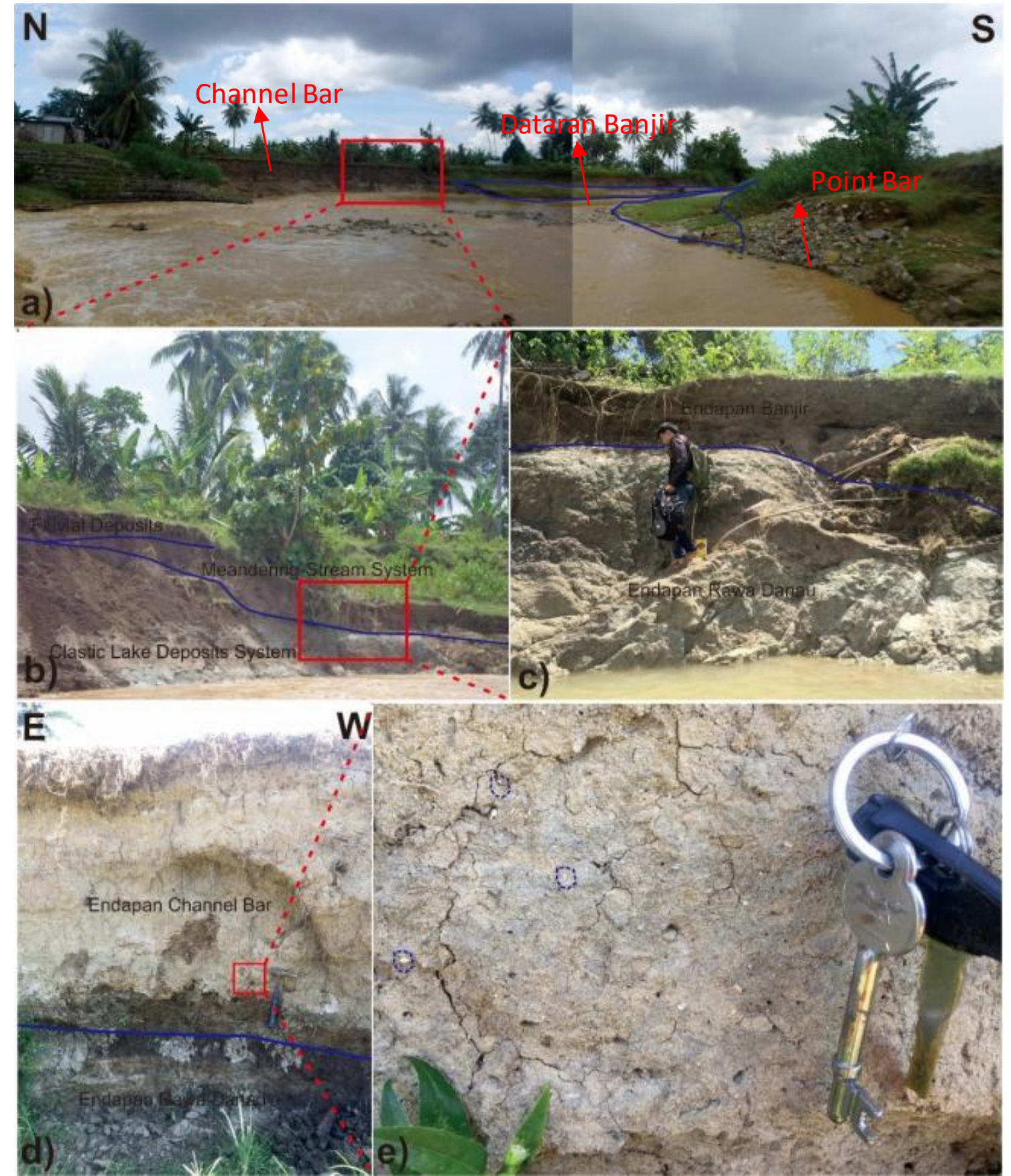

Gambar 9. Subfasies rawa danau, dataran banjir dan endapan channel, a) kenampakan kontrol morfologi terhadap fasies pengendapan; b) dan c) fasies clastic lake deposits dan meandering-channel system (BR001 dan BR002); d) dan e) kenampakan fosil moluska air tawar berupa gastropoda (BR017).

ditemukan didominasi oleh pasir dan setempat lempung bersifat lepas serta banyak ditemukan sisa-sisa akar dan aktivitas-aktivitas antropogenik berupa limbah manusia. Pada fasies ini juga ditemukan banyak distribusi perlapisan laminasi silang-siur dan paralel (Gambar 9).

\subsection{Penyebaran Fasies Pada Daerah Penelitian}

Keberadaan Danau Limboto dimulai pada Holosen tepatnya terpisah dari muka air laut (Nugraha \& Hall, 2018). Tersebar hampir secara keseluruhan pada daerah cekungan Limboto (Bawono et al., 1999), dimana cakupan danau ini berkisar pada 10.000 tahun lalu dikarenakan aktivitas pendangkalan yang cukup tinggi sehingga membuat perubahan luas Danau (Putra et al., 2012).

Pada sekitar $<2500$ tahun lalu dari tinggi aktivitas erosi dan pendangkalan dari Danau Limboto menyebabkan luas danau berkurang hingga sekitar 50\% dari luas danau pada 10.000 tahun lalu. Hal tersebut berdasarkan dari data pengeboran dan carbon dating pada endapan-endapan disekitar cekungan Limboto yang dilakukan oleh BWS Sulawesi II (2018a), serta di interpolasikan dari data DEM SRTM. Pada saat ini juga dapat dapat terlihat keadaan Danau Limboto yang mengalami perubahan luas danau 


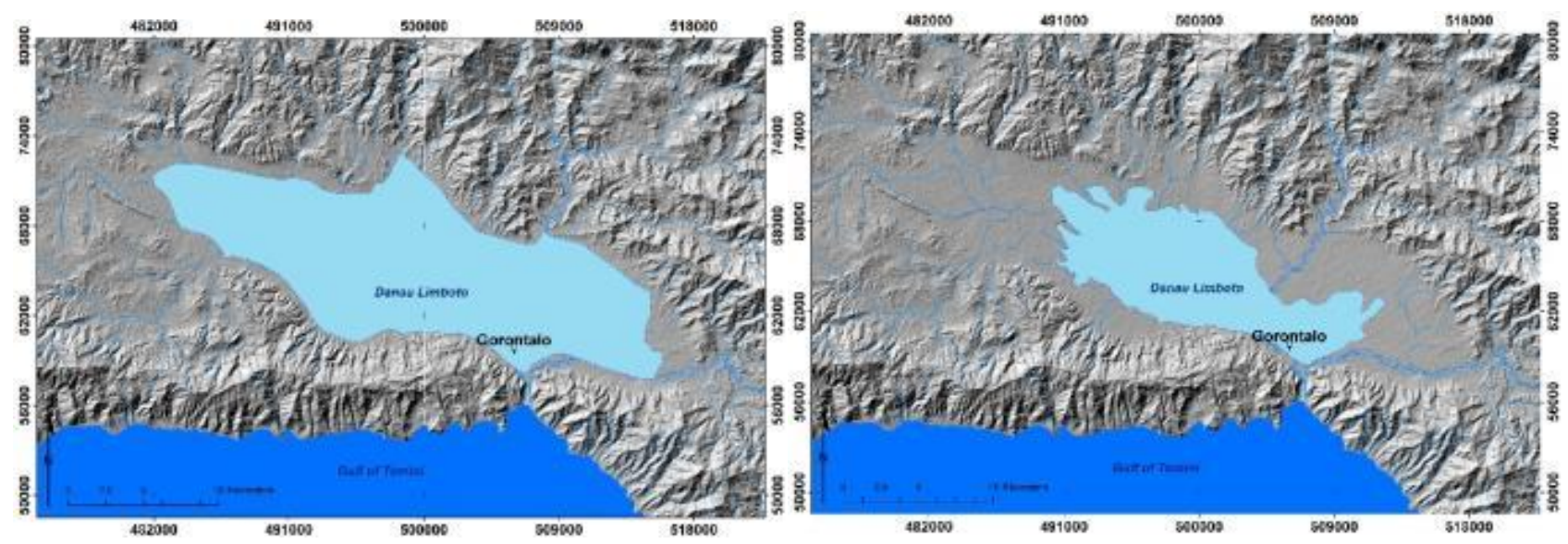

Gambar 10. Danau Limboto pada $<10.000$ tahun lalu (Bawono et al., 1999) (Kiri); Danau Limboto pada $<2.500$ tahun dari interpolasi DEM SRTM dengan Carbon Dating oleh BWS Sulawesi II (2018a) (Kanan).

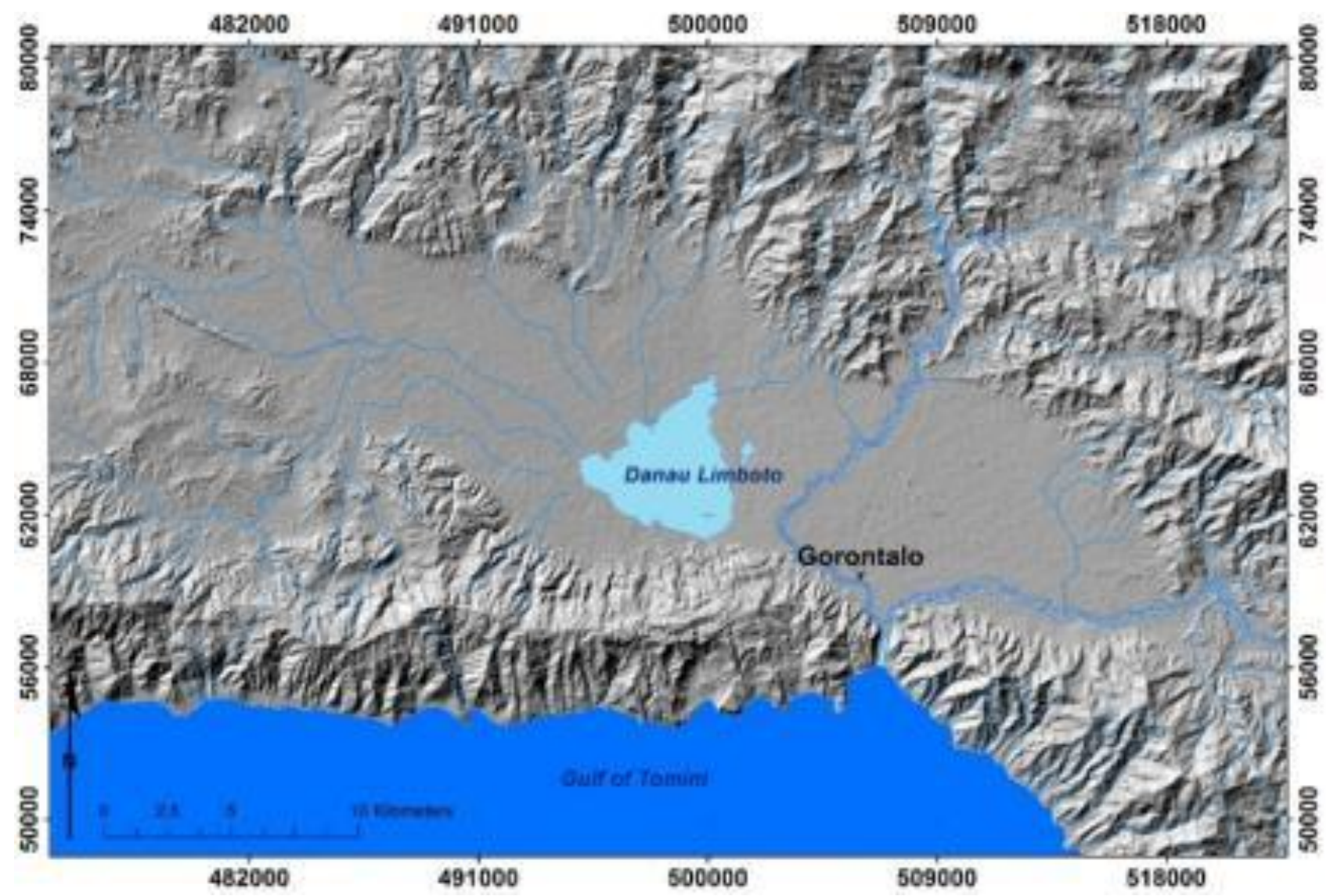

Gambar 11. Danau Limboto saat ini

yang cukup signifikan pada 10 tahun terakhir berdasarkan foto udara dan citra Worldview kawasan Danau (Gambar 10 dan Gambar 11).

Dari perubahan-perubahan luas Danau Limboto dari kurun waktu beberapa tahun terakhir, dapat disimpulkan bahwa Danau Limboto terancam dapat hilang dalam kurun waktu beberapa tahun kedepan, sehingga diperlukan berbagai tindakan yang berarti dari berbagai stake-holder yang memiliki kepentingan terhadap keberlangsungan danau ini.

Pola penyebaran fasies lake margin clastic deposits pada daerah penelitian disimpulkan berdasarkan hasil fasies yang mendominasi pada data penampang stratigrafi, terlihat perubahan yang signifikan pada subfasies lake margin clastic deposits dalam kurun waktu 10.000 tahun terakhir hingga saat ini. Pola penyebaran fasies ini mendeskripsikan aktivitas transportasi sedimentasi yang cukup tinggi pada Danau Limboto (Gambar 12). 


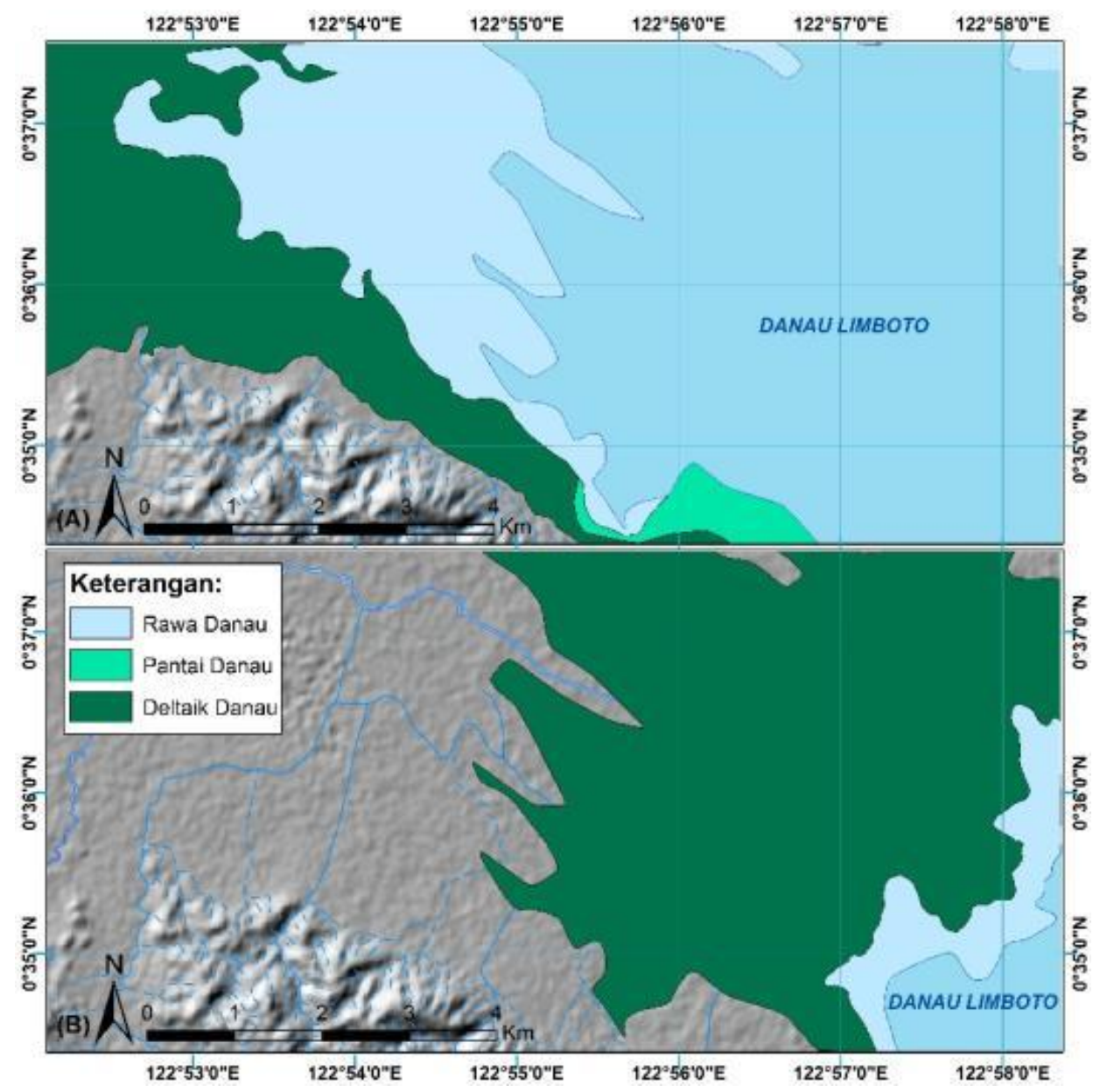

Gambar 12. Pola penyebaran fasies lake margin clatic deposits pada daerah penelitian (a) $10.000-2500$ tahun (b) 2500 tahun - saat ini. (Dinterpolasi dari data penampang stratigrafi dan DEM SRTM).

Subfasies deltaik fasies dicirikan oleh keybed berupa penyebaran struktur laminasi sejajar dan setempat laminasi silang siur yang mendominasi pada lapisan pasir yang mengindikasikan adanya aktivitas-aktivitas saluran sungai pada fasies ini. Subfasies rawa danau dicirikan oleh keybed lapisan lempung yang banyak mengandung sisa-sisa tumbuhan dan cangkang moluska air tawar. Sementara subfasies pantai danau banyak berupa endapan pasir yang setempat terisi oleh pecahan-pecahan terumbu dengan karakteristik pasir yang sangat retas dengan campuran lempung yang rendah.

\section{Kesimpulan}

Fasies dan lingkungan pengendapan daerah penelitian, dibagi menjadi dua formasi utama yaitu formasi non-endapan danau dan formasi endapan danau. Formasi non-endapan danau yaitu satuan batugamping klastik yang berumur akhir Miosen Akhir hingga akhir Pliosen Awal terendapkan di zona neritik tengah hingga neritik luar, satuan batugamping terumbu berumur akhir Miosen Akhir hingga awal Pliosen Akhir diendapkan pada zona neritik dalam hingga neritik tengah, satuan batupasir dibandingkan dengan formasi Molasa Selebes dan formasi Endapan Teras sehingga diendapakan di daerah cekungan pasca orogenik terakhir berumur Pliosen Akhir hingga Plistosen dan Formasi endapan danau satuan lempung dibandingkan dengan formasi Endapan Danau di endapakan pada daerah cekungan-cekungan darat berumur Holosen dan terendapkan hingga saat ini dan terakhir satuan lempung pasiran yang merupakan endapan fluvial dan masih terendapkan hingga saat ini

Secara keseluruhan lokasi penelitian terdiri dari zona pengendapan laut, transisi serta teresterial. Diperlihatakan dari adanya endapan penciri lingkungan pengendapan laut, lingkungan pengendapan transisi dan teresterial. Fokus studi pada tugas akhir ialah fasies dan lingkungan pengendapan Formasi Endapan Danau dimana mulai diendapkan pada kala Holosen hingga saat ini oleh aktivitas pengendapan di daerah teresterial, tidak mencirikan adanya pengaruh aktivitas air laut sehingga disimpulkan bahwa pengendapannya dikontrol oleh air tawar. Formasi Endapan Danau tersebar merata hampir di seluruh cekungan Limboto yang terdiri atas lingkungan lake margin clastic deposit dan meandering-stream deposit. 


\section{Ucapan Terima Kasih}

Ucapan terimakasih kepada seluruh pihak terkait yang telah membantu terselesaikannya penelitian ini. Professor Masayuki Sakakibara dari Ehime University dan Professor Emy Suparka dari Institut Teknologi Bandung, yang telah membantu dalam analisis data petrografi, Patra Embara, ST dari PT. Suwanda Karya Mandiri yang telah memberikan kontribusi data penelitian.

\section{Referensi}

Apandi, T. \& Bachri, S., 1997. Geological map of the Kotamobagu sheet. Sulawesi Map.

Bawono, S., S., Partoyo, E., Wirosujono, S., Situmorang, R., I., \& Spandjojo R., J., B. 1990 Peta geologi Lembar Limboto, Sulawesi skala 1:100.000. . Pusat Penelitian dan Pengembangan Geologi. Bandung.

[BIG] Badan Informasi Geospasial. 2013. Peta Rupa Bumi Indonesia, lembar 2216-621 Dan Lembar 2216-622 Limboto skala 1:25.000. Indonesia.

Blow, H., 1969. The Late Middle Eocene to Recent Planktonic Foraminiferal Biostratigraphy. International Confernece Planktonic Microfossil. 1967. Proceeding., Bull Vol 1

[BWS] Balai Wilayah Sungai Sulawesi II. 2018a. Analisis Seismic Hazard : DD dan Sertifikasi Desain Bendungan Bolango Ulu (MYC). Tidak diterbitkan. Laporan Internal. Kementerian Pekerjaan Umum dan Perumahan Rakyat. Jakarta.

[BWS] Balai Wilayah Sungai Sulawesi II. 2018b. Desain Penataan Kawasan Danau Limboto. Laporan Internal. Kementerian Pekerjaan Umum dan Perumahan Rakyat. Jakarta.

Embry, R.J., \& Klovan, J.E., 1971. A Late Devonian Reef Tract on Norteastern Bank Island, N.W.T. Bulletin of Canadian Petroleum Geology 19(4):730-781.

Nugraha, A., M., S., \& Hall, R., 2018. Late Cenozoic paleogeography of Sulawesi, Indnesia. Paleogeography, Paleoclimatology, Paleoecology, 3. 490:191-209

Pettijohn, F.J., 1975. Sedimentary Rocks $3^{\text {rd }}$ ed. Harper and Row. New York

Putra, S., S., Hassan C., Djudi, Suryatmojo, H., 2012. Resevoir Saboworks Solutions in Limboto Lake Sedimentations, Northern Sulawesi, Indonesia. The $3^{\text {rd }}$ International Conference on Sustainable Future for Human Security SISTAIN 2012. Procedia Environmental Sciences. 17(2013):230-239.

Rudyawan, A., Hall, R., \& White, L,. 2014. Neogene Extension of the Central North Arm of Sulawesi, Indonesia. American Geophysical Union, Fall Meeting. December 2014. San Fransisco.

Satyana A. H., Faulin T., \& Mulyati S., N., 2011. Tectonic Evolution Of Sulawesi Area: Implications For Proven And Prospective Petroleum Plays. Proceedings JCM Makassar 2011. The $36^{\text {th }}$ HAGI and $40^{\text {th }}$ IAGI Annual Convention and Exhibition. Makassar.

Tipsword, H.J., Setzer, F.M., \& Smith, Jr., F.L., 1966. Interpretation of Depositional Environment in Gulf Coast Petroleum Exploration from Paleoecology and Related Stratigraphy: Transactions of the Gulf Coast. Association of Geological Societies 16:119-130

Van Leeuwen, T. M. \& Muhardjo. 2005. Stratigraphy and tectonic setting of the Cretaceous and Paleogene volcanic-sedimentary successions in northwest Sulawesi, Indonesia: implications for the Cenozoic evolution of Western and Northern Sulawesi. Journal of Asian Earth Sciences 25:481-511. 
Lampiran. Profil vertikal

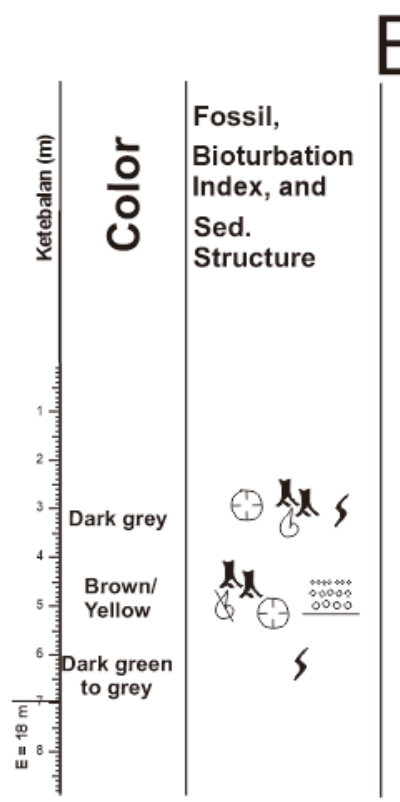

$\mathrm{BrO01}$
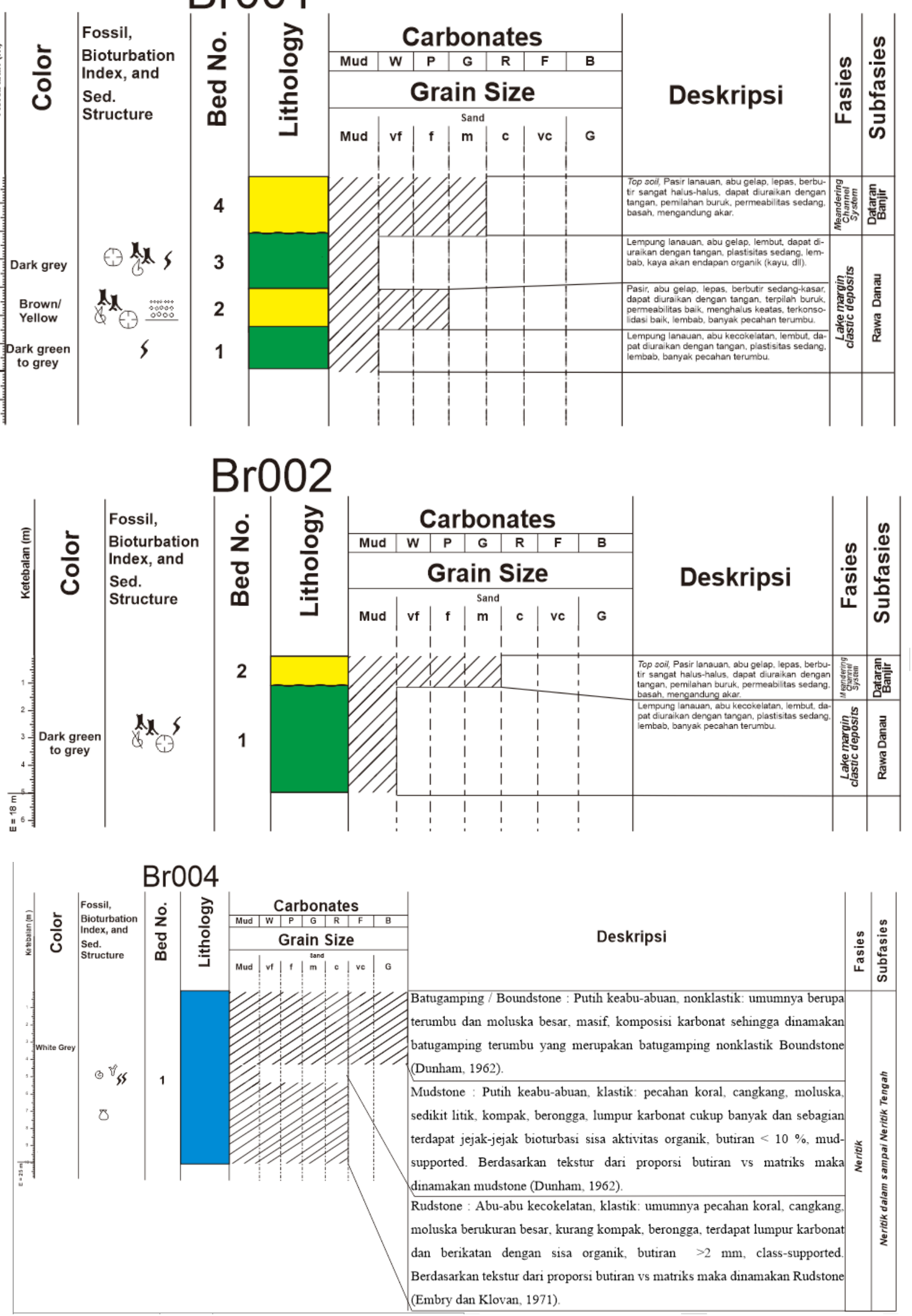

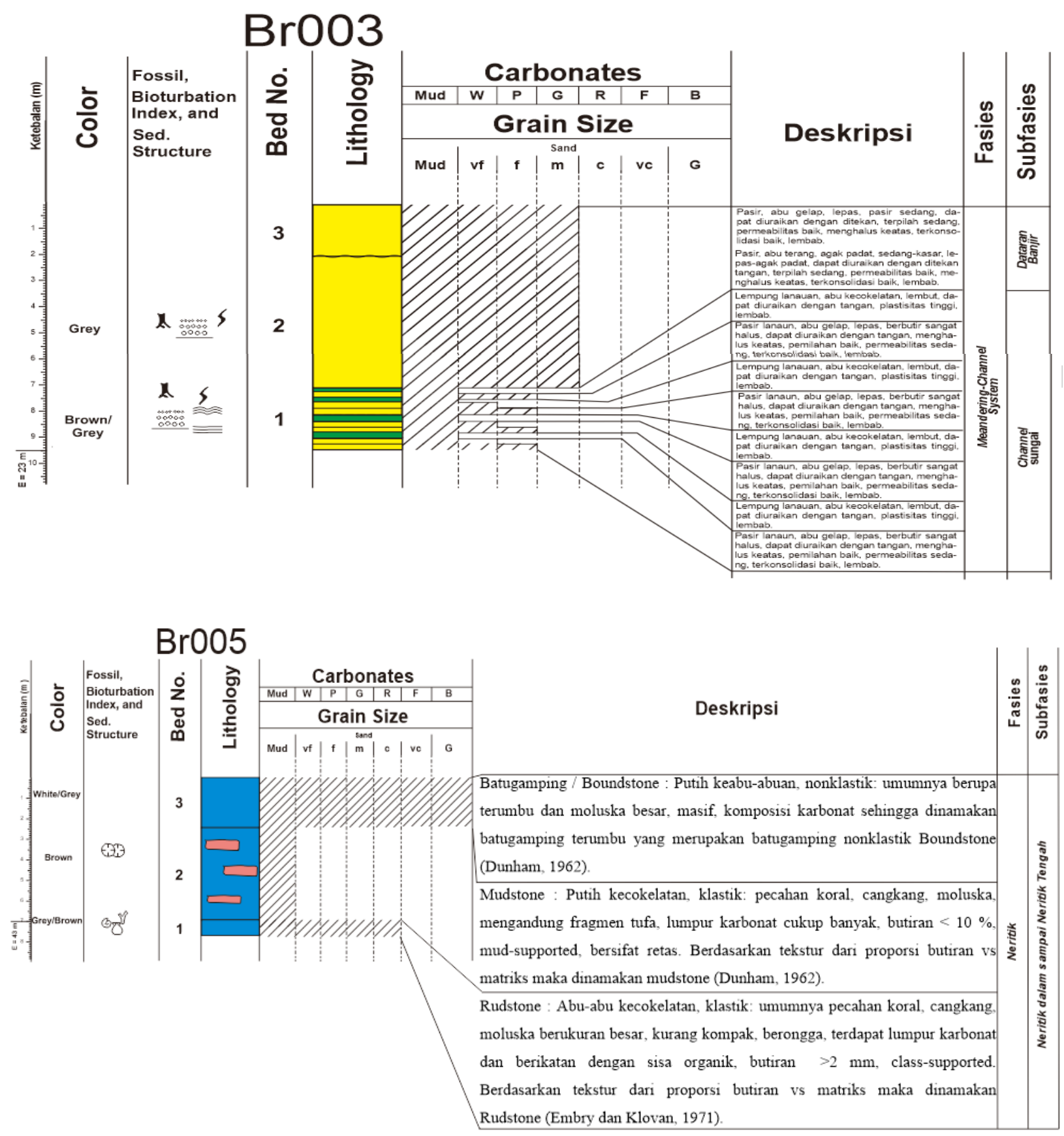

\section{Br006}

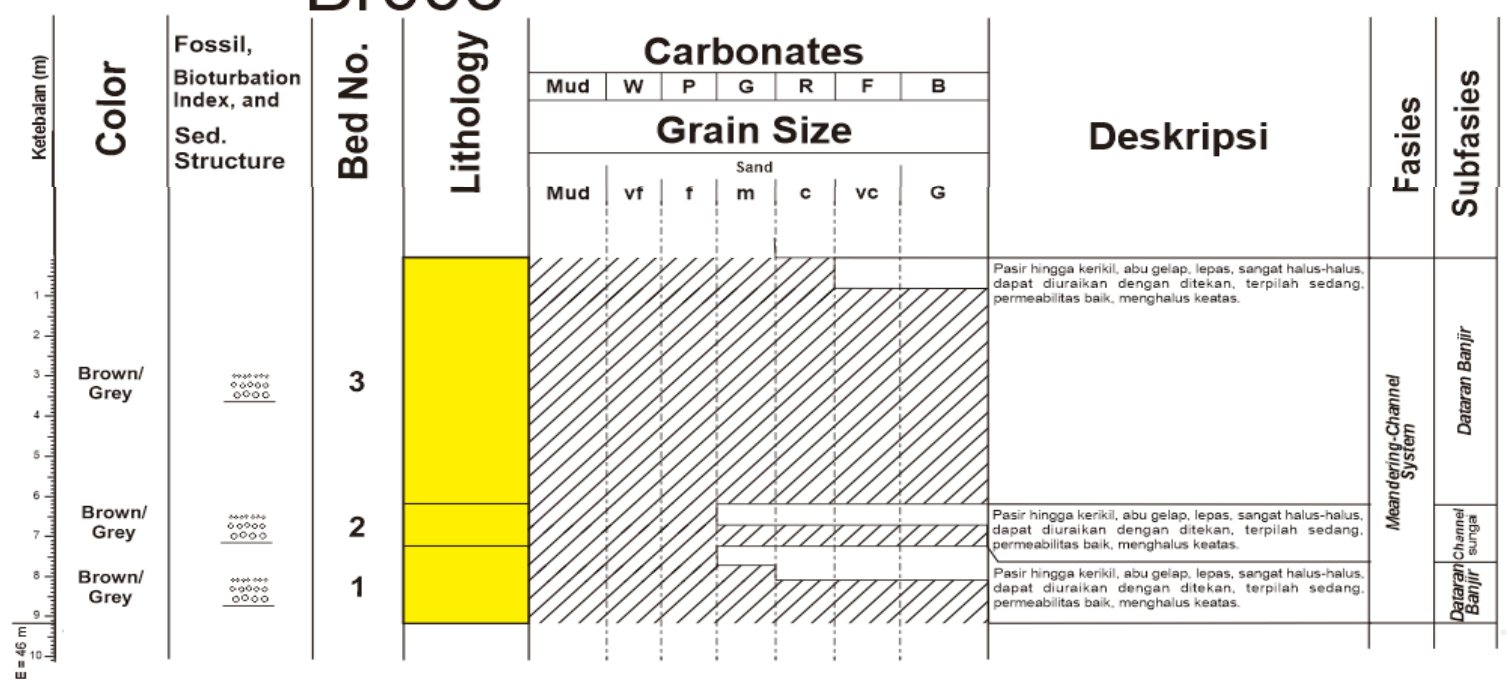




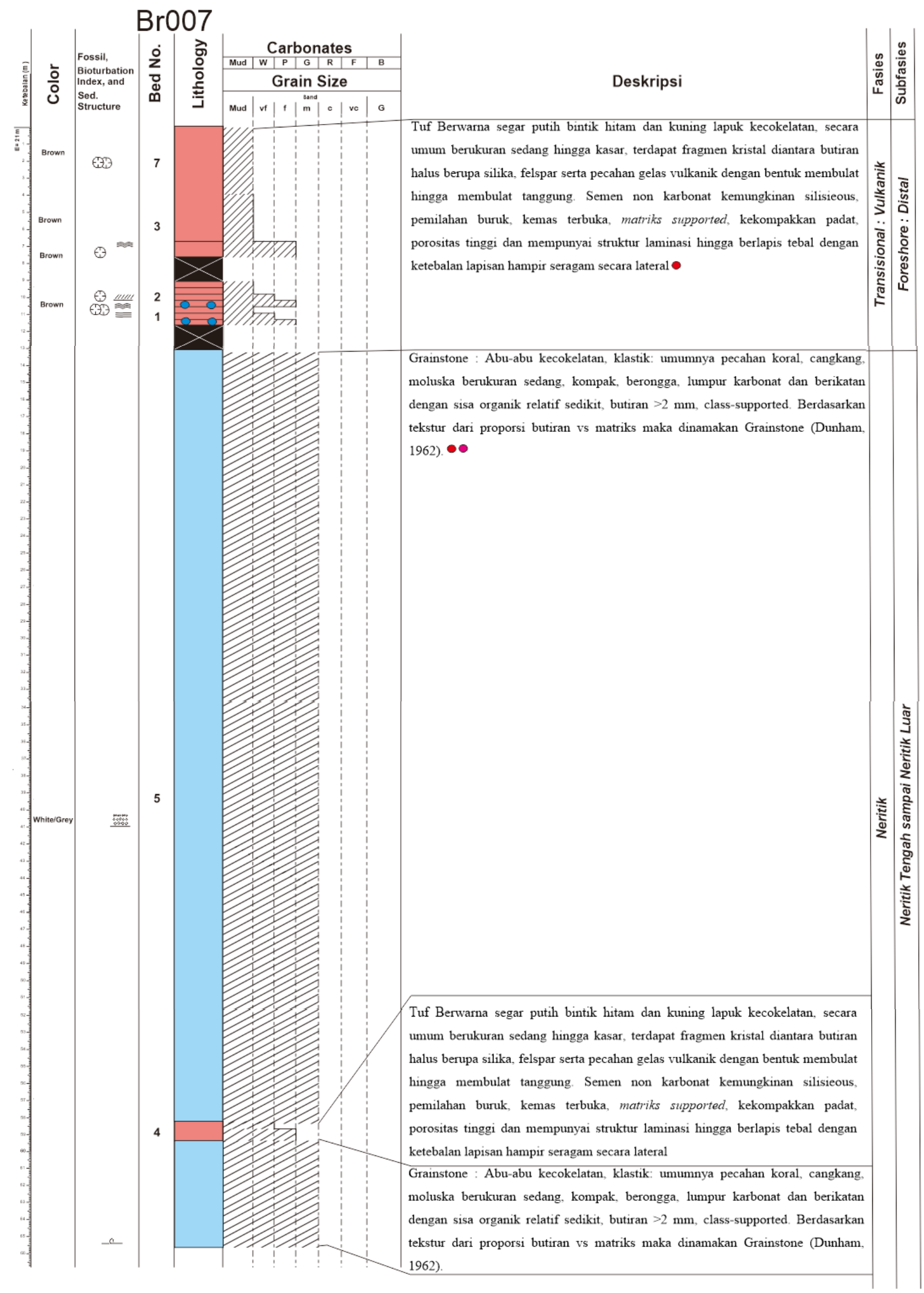



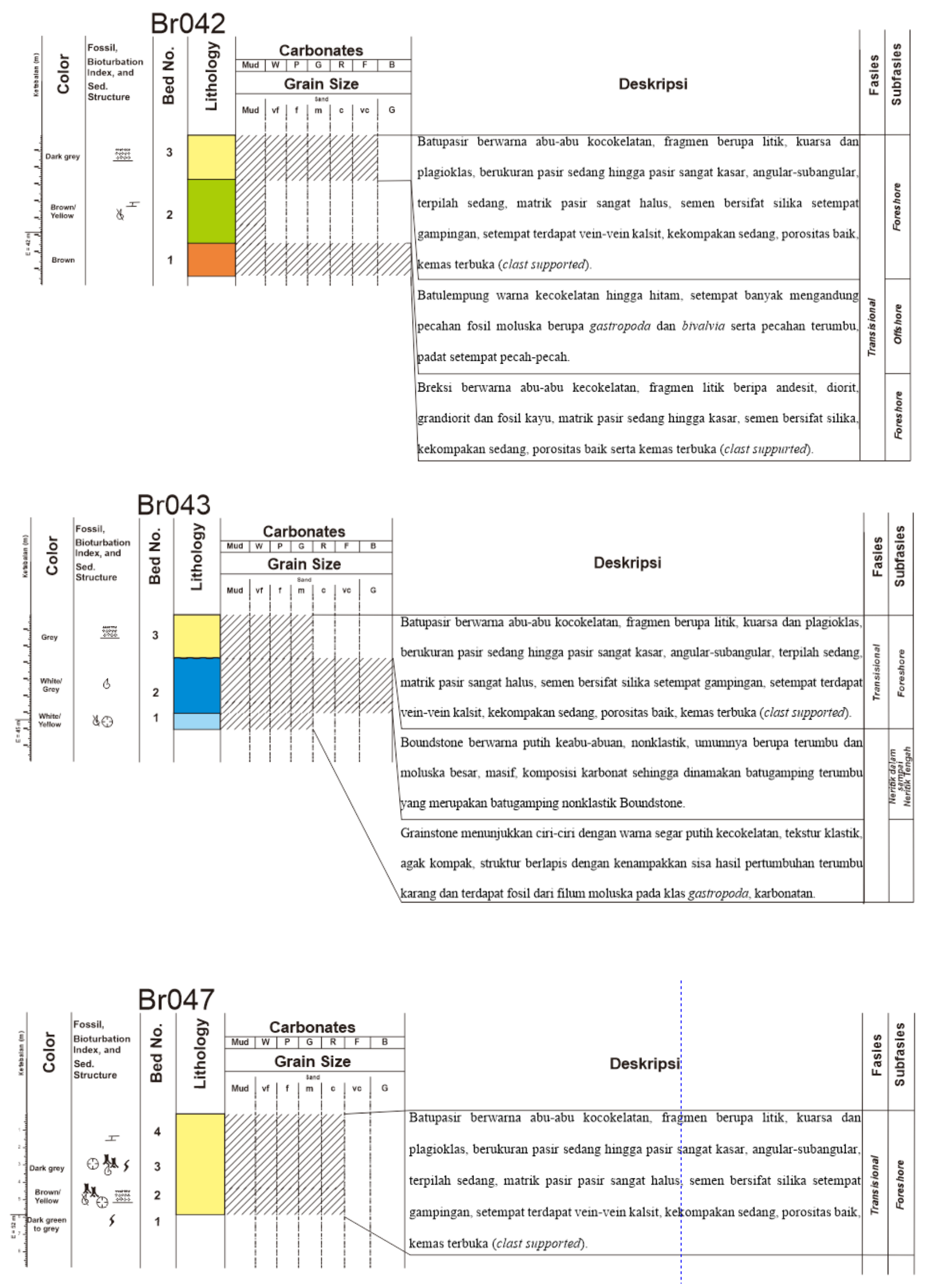


\section{Legend:}

6 Fossils (undiferentiated)

\& Fossils-broken

o ammonoids

o Bivalves

$f$ - ...

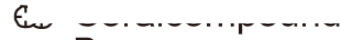

$\checkmark$ Bryozoans

a Roots

$\checkmark$ Slight $\}$ Bioturbation

sormal graded

= Parallel lamination

$\approx$ Wave lamination

«u Cross lamination

_c Flame structure

I Chalcareous

Petrography

Microfossil

Carbon dating

\section{Data Mikrofossil}

$\begin{array}{lll}\text { Kode } & : & \text { Stasiun BR033 } \\ \text { Lokasi } & : & \text { Desa Tabongo Barat } \\ \text { Batuan } & : & \text { Napal (Pettijohn, 1975) } \\ \text { Pengamatan } & : & \text { Foraminifera kecil }\end{array}$

\begin{tabular}{|c|c|c|c|c|c|c|c|c|}
\hline \multirow{3}{*}{$\frac{\text { BR } 033}{\text { No. }}$} & \multirow{3}{*}{\begin{tabular}{|l} 
BENTONIK \\
\\
Spesies
\end{tabular}} & \multicolumn{7}{|c|}{ Kedalaman (Zonasi Tipsword, 1966) } \\
\hline & & Litoral & Neritik dalam & Neritik tengah & Neritik luar & Batial atas & Batial bawah & Abisal \\
\hline & & & 0 & \begin{tabular}{|l|l}
20 \\
\end{tabular} & 100 & \begin{tabular}{|l|l}
200 &
\end{tabular} & \begin{tabular}{|l|l}
500 &
\end{tabular} & 2000 \\
\hline 1 & Lenticulina sp. & & & & & & & \\
\hline 2 & Amphistegina lessonii & & & & & & & \\
\hline 3 & Elphidium crispum & & & & & & & \\
\hline 4 & Ammonia inflata & & & & & & & \\
\hline 5 & Ammonia beccarii & & & & & & & \\
\hline 6 & Elphidium macellum & & & & & & & \\
\hline 7 & Operculina ammonoides & & & & & & & \\
\hline 8 & Cancris auriculus & & & & & & & \\
\hline 9 & Cibicides sp. & & & & & & & \\
\hline \multicolumn{9}{|l|}{10} \\
\hline 11 & & & & & & & & \\
\hline & & & & & & & & \\
\hline
\end{tabular}

\begin{tabular}{|c|c|c|c|c|c|c|c|c|c|c|c|c|}
\hline \multirow[t]{4}{*}{ BR 033} & \multicolumn{12}{|c|}{ PLANKTONIK } \\
\hline & \multirow{3}{*}{ Spesies } & \multicolumn{11}{|c|}{ Umur (Zonasi Blow, 1969) } \\
\hline & & \multicolumn{2}{|c|}{ Miosen Tengah } & \multicolumn{3}{|c|}{ Miosen Akhir } & \multicolumn{2}{|c|}{ Pliosen Awal } & \multicolumn{2}{|c|}{ Pliosen Akhir } & \multicolumn{2}{|c|}{ Plistosen } \\
\hline & & N13 & N14 & N15 & N16 & N17 & N18 & N19 & $\mathrm{N} 2 \mathrm{O}$ & N21 & N22 & N23 \\
\hline 1 & Orbulina universa & & & & & & & & & & & \\
\hline 2 & Globorotalia humerosa & & & & & ב & & & 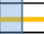 & & & \\
\hline 3 & Globigerinoides $s p$. & & & & & & & & & & & \\
\hline 4 & Globorotalia menardii & & & & & & & & $E$ & & & \\
\hline 5 & Globigeina bulloideus & & & & $=$ & & & & - & & & \\
\hline 6 & Globigerinoides ruber & & & & & - & & & 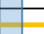 & & & \\
\hline 7 & Globigemoides trilobus trilobus & & & & & - & & & $\theta$ & & & \\
\hline 8 & Pulleniatina primalis & & & & & & & . & 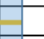 & & & \\
\hline & & & & & & & & & & & & \\
\hline & & & & & & & & & & & & \\
\hline
\end{tabular}

Interpretasi

: Berdasarkan asosiasi foraminifera bentik yang hadir, sampel ini diendapkan pada lingkungan neritik dalam - neritik tengah. Adanya foraminifera besar seperti amphistegina dan operculina menunjukkan lingkungan yang masih dangkal. Namun kelimpahan foraminifera planktonik hanya sekitar 10\%, hal ini menunjukkan lingkungan yang lebih dangkal, pada neritik dalam-neritik tengah.

Umur

: Akhir Miosen Akhir - Awal Pliosen Akhir (Blow, 1969)

Lingkungan Pengendapan : Neritik Tengah - Neritik Dalam $(0-20$ m) (Tipsword et al., 1966) 
Kode : Stasiun BR007

Lokasi : Desa Tabongo Barat

Batuan : Grainstone (Embry \& Klovan, 1971)

Pengamatan : Foraminifera kecil

\begin{tabular}{|c|l|l|l|l|l|l|l|l|}
\hline BR 007 & BENTONIK & \multicolumn{5}{|c|}{ Kedalaman (Zonasi Tipsword, 1966) } \\
\hline \multirow{2}{*}{ No. } & \multicolumn{1}{|c|}{ Spesies } & Litoral & Neritik dalam & Neritik tengah & Neritik luar & Batial atas & Batial bawah & Abisal \\
\hline & & & 0 & 20 & 100 & 200 & 500 & 2000 \\
\hline 1 & Cancris auriculus & & & & & & & \\
\hline 2 & Lenticulina cultrata & & & & & & & \\
\hline 4 & Cibicidoides sp. & & & & & & & \\
\hline 5 & Amphistegina lessonii & & & & & & & \\
\hline 6 & Cibicides sp. & & & & & & & \\
\hline 7 & Elphidium macellum & & & & & & & \\
\hline 8 & Triloculina trigonula & & & & & & & \\
\hline 9 & Quinqueloculina spp. & & & & & & & \\
\hline 10 & Textularia aglutinans & & & & & & & \\
\hline 11 & Operculina ammonoides & & & & & & & \\
\hline 12 & Elphidium advenum & & & & & & & \\
\hline 13 & Ammonia beccarii & & & & & & & \\
\hline 14 & Bolivina spp. & & & & & & & \\
\hline 15 & Discorbis sp. & & & & & & \\
\hline 16 & Elphidium crispum & & & & & & \\
\hline
\end{tabular}

\begin{tabular}{|c|c|c|c|c|c|c|c|c|c|c|c|c|}
\hline \multirow[t]{4}{*}{ BR 007} & \multicolumn{12}{|c|}{ PLANKTONIK } \\
\hline & \multirow{3}{*}{ Spesies } & \multicolumn{11}{|c|}{ Umur (Zonasi Blow, 1969) } \\
\hline & & \multicolumn{2}{|c|}{ Miosen Tengah } & \multicolumn{3}{|c|}{ Miosen Akhir } & \multicolumn{2}{|c|}{ Pliosen Awal } & \multicolumn{2}{|c|}{ Pliosen Akhir } & \multicolumn{2}{|c|}{ Plistosen } \\
\hline & & N13 & N14 & N15 & N16 & N17 & N18 & N19 & $\mathrm{N} 2 \mathrm{O}$ & N21 & $\mathrm{N} 22$ & $\mathrm{~N} 23$ \\
\hline 1 & Globigerinoides trilobus trilobus & & & & & & & & & & & \\
\hline 2 & Globigerina bulloides & & & & & & & & & & & \\
\hline 3 & Globigerinoides trilobus immaturus & & & & & & & & & & & \\
\hline 4 & Orbulina universa & & & & & & & & & & & \\
\hline 5 & Globoquadrina dehiscens & & & & & & & & & & & \\
\hline 6 & Globigerinoides ruber & & & & & & & & & & & \\
\hline 7 & Globigerinoides trilobus sacculiferus & $t$ & & & & & & & & & & \\
\hline 8 & Globorotalia humerosa & & & & & & & & & & & \\
\hline 9 & Neogloboquadrina sp. & & & & & & & & & & & \\
\hline 10 & Globorotalia obesa & & & & & & & & & & & \\
\hline 11 & Globigerinoides obliquus extremus & & & & & & & & & & & \\
\hline 12 & Pulleniatina primalis & & & & & & . & 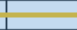 & - & & & \\
\hline & & & & & & & & & & & & \\
\hline
\end{tabular}

\section{Interpretasi}

: Genus-genus yang hadir pada sampel ini merupakan genus penciri lingkungan neritik tengah - neritik luar. Adanya foraminifera besar seperti amphistegina dan operculina menunjukkan lingkungan yang masih dangkal. Kelimpahan foraminifera planktonik hanya sekitar $30 \%$.

Umur $\quad$ : Awal Miosen Akhir - Akhir Pliosen Awal (Blow, 1969)

Lingkungan Pengendapan $\quad$ : Neritik Tengah - Neritik Luar $(20-100$ m) (Tipsword et al., 1966) 